\title{
A COMPARATIVE STUDY OF JUTE FIBER REINFORCED CONCRETE WITH PLAIN CEMENT CONCRETE
}

\author{
T. Sai Vijaya Krishna', B. Manoj Yadav ${ }^{2}$ \\ ${ }^{1}$ Assistant Professor, QIS College of Engineering \\ ${ }^{2}$ Professor, QIS College of Engineering
}

\begin{abstract}
This work aims to study the behaviour of jute fibers mixed in concrete as a reinforcing material for improving the mechanical properties of concrete. Several experiments were conducted on jute fibers, jute-cement mortar and jute fiber reinforced concrete in this research. For this study, a total of 24 mortar specimens for compressive strengths and 144 concrete specimens i.e. 48 cubes, 48 prisms and 48 cylinders each consisting of ordinary concrete, 0.5\%, $1 \%$ and $2 \%$ Jute fiber reinforced concrete are tested for their compressive, flexural and split tensile strengths respectively for different curing periods such as 7, 28, 56 and 90 days.It is observed that the JFRC specimens with $1 \%$ jute content, cured up to 56 days has significant improvement of mechanical properties such as compressive strength, flexural strength and split tensile strength with respect to ordinary concrete.
\end{abstract}

$* * *$

\section{INTRODUCTION}

Recent advancements and research in material technology has led to the development of special concretes such as polymer concrete for high durability, fiber reinforced concrete for preventing cracks in concrete, high- and ultra high-strength concrete for applications in tall buildings and bridges, light weight concrete for reducing foundation loads, and high performance concrete for special performance requirements.

In both developing and developed countries, it has been a technological challenge in the field of the design of low cost and durable fiber reinforced cement concrete.The type of fibers currently been used include steel, carbon, polymers, glass and natural fibers. Cost-effective considerations have limited the usage of carbon fibers in cementitious composites on a marketable level for their non-ecological performance. Natural fibers have the potential to be used as reinforcement to sceptical the innate scarcities in cementitious materials. Substantial researches are being done for usage of reinforcing fibers like jute, akwara, sisal, bamboo, sugarcane bagasse, coconut husk in cement composites typically in case of building materials.

This research work mainly deals with fiber-reinforced concrete i.e. with jute as a fiber reinforcing material in concrete. Usage of natural fibers in a relatively brittle cement matrix has attained significant toughness and strength of the composite. Effective modifications are to be done for such fibers to attain durability in a highly alkaline cement matrix. An explicit chemical composition has to be preferred that can transform the fiber surface as well as reinforce the cement composite.

\section{EXPERIMENTAL INVESTIGATION}

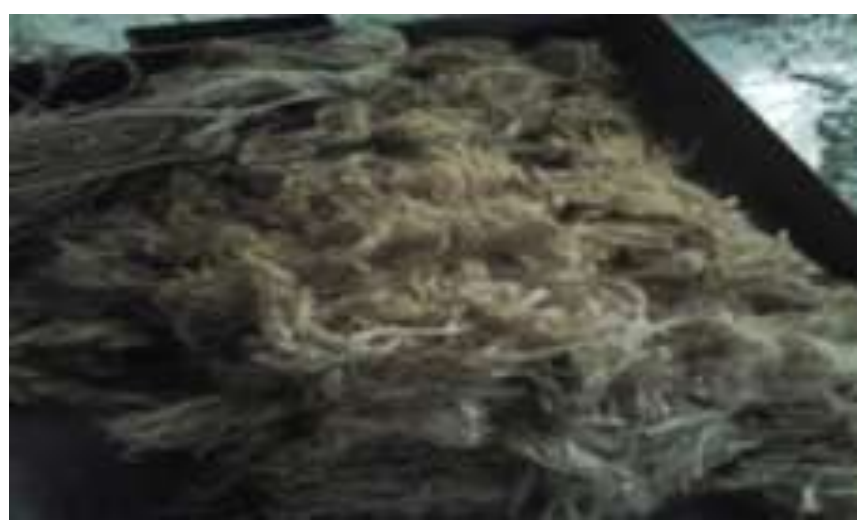

\subsection{Materials}

Jute fibers (grade-bright) were collected from Nellimarla jute mills, Vizianagaram, Andhra Pradesh (India).

Cement used is of OPC 53 grade JAYPEE cement. The coarse and fine aggregate are obtained from local dealers.

\subsection{Tests on Materials}

\subsubsection{Jute Fibers: The following are the Tests that} are conducted On Jute Fibers

i. Water absorption: The water absorption study of jute fibers was done in accordance with ASTM D570-98. The oven dried jute fibers are shown in Fig. 1. 


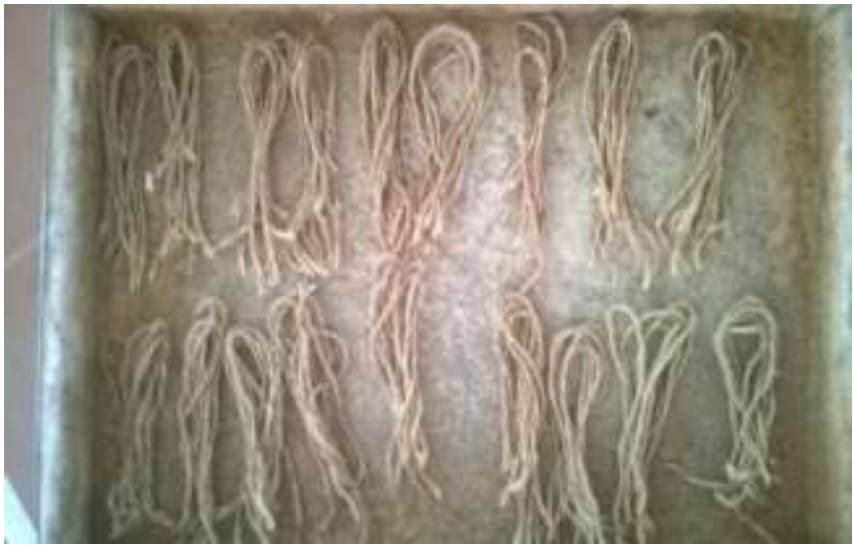

Fig. 1. Oven dried Jute Fibers

The water absorption is calculated as

Water absorption $(\%)=\left[\frac{w_{2}-w_{1}}{w_{1}}\right] \times 100$

where,

$\mathrm{w}_{1}$ is the initial weight of oven dried jute fiber before water absorption and

$\mathrm{w}_{2}$ is the weight of jute fiber after water absorption.

ii. Tensile strength and \% of Elongation:

The tensile properties of the jute fibers were measured using Universal Testing Machine 20K tensile testing machine. For more accuracy some of the samples of fibers are tested manually with loading the fibers with weights and tensile strength is obtained by using a simple formula as follows

Tensile strength of jute fiber

$(\sigma)=\frac{\text { Load applied on the sample }(\mathrm{P})}{\text { Area of the fiber }(\mathrm{A})}$

Area of the fiber $(\mathrm{A})=\frac{\pi \mathrm{d}^{2}}{4}$

Diameter "d" of the fiber is obtained using screw gauge

While conducting the tensile strength test the fiber tends to elongate and this elongation is also recorded. The percentage elongation at break of the jute fibers are calculated and are found to be varying with modification of jute fibers.

\subsubsection{Test on Cement Paste Reinforced with Jute}

\section{Fibers}

i. Standard consistency:

The standard consistency test is as per IS: 4031-1988 (Part 4) and while conducting the test the jute fibers are also added in $0.5 \%, 1 \%$ and $2 \%$ w. r. t. weight of cement and its behaviour is observed.

ii. Setting time characteristics:

The setting time of cement paste is conducted as per IS: 4031-1988 (Part 5) and during the test the jute fibers of $0.5 \%, 1 \%$ and $2 \%$ w.r.t. cement is added to cement paste and its behaviour is observed.

iii. Compressive Strength of cement:

The compressive strength of cement mortar is conducted as perIS: 4031-1988 (Part 6) and while preparing the test specimens,jute fibers of $0.5 \%, 1 \%$ and $2 \%$ content w.r.t. cement are also added to cement mortar and the behaviour is observed.

\subsection{Casting and Curing of Concrete Specimens}

The concrete specimens such as cubes of size $150 \mathrm{~mm} \times 150$ $\mathrm{mm} \times 150 \mathrm{~mm}$, cylinders of $150 \mathrm{~mm}$ diameter and $300 \mathrm{~mm}$ height, prisms of size $500 \mathrm{~mm} \times 100 \mathrm{~mm} \times 100 \mathrm{~mm}$ are casted as per the standards with different jute contents such as $0 \%, 0.5 \%, 1 \%$ and $2 \%$.

The casted specimens are then cured for different periods of 7, 28, 56 and 90 days.

\subsection{Testing of Concrete Specimens}

After the curing period is completed, the specimens are tested for the following tests:

a) Compressive strength of Concrete:

The concrete and JFRC cube specimens of size $150 \mathrm{~mm}$ $\times 150 \mathrm{~mm} \times 150 \mathrm{~mm}$ are tested for compressive strength as per Sec. 5 of IS:516 -1959.

b) Flexural strength of Concrete:

The concrete and JFRC prism specimens of size 500 $\mathrm{mm} \times 100 \mathrm{~mm} \times 100 \mathrm{~mm}$ are tested for the flexural strength as per Sec. 8 of IS: 516-1959.

c) Split tensile strength of Concrete:

The concrete and JFRC cylinder specimens of size 150 $\mathrm{mm}$ diameter and $300 \mathrm{~mm}$ height are tested for the split tensile strength as per IS: 5816 - 1999.

\section{RESULTS AND DISCUSSIONS}

The following are the results obtained from the above explained tests:

\subsection{Jute Fibers}

From the tests conducted on jute fibers, the water absorption, tensile strength and the percentage elongation are observed as follows:

Water absorption $=205.26 \%$

Tensile strength $=262.6 \mathrm{MPa}$

$\%$ elongation $=1.16 \%$

\subsection{Cement Paste Reinforced with Jute Fibers}

a) Standard Consistency

The jute fibers are chopped in to $25 \sim 30 \mathrm{~mm}$ pieces and is then mixed with cement paste to check the standard consistency behaviour of cement paste. The Table.1 shows the variation of standard consistency with respect to variation in jute loading. 
Table. 1:Standard Consistency with variation in Jute Content

\begin{tabular}{|l|l|l|}
\hline Description & $\begin{array}{l}\text { Jute } \\
\text { Loading } \\
(\%)\end{array}$ & $\begin{array}{l}\text { Standard } \\
\text { Consistency } \\
\text { (W/C) }\end{array}$ \\
\hline Control & 0 & 0.34 \\
\hline RJC & 0.5 & 0.38 \\
\hline RJC & 1 & 0.40 \\
\hline RJC & 2 & 0.42 \\
\hline
\end{tabular}

From the results, it is observed that as the jute content increases, the amount of water required for making the cement as paste also has been increased.

b) Setting Time characteristics:

The jute fibers are chopped in to $25 \sim 30 \mathrm{~mm}$ pieces and is then mixed with cement paste to check the setting time characteristics i.e. initial and final setting time of cement paste with different loadings of jute such as $0.5 \%, 1 \%$ and $2 \%$ w.r.t. weight of cement. The setting time characteristics are observed as shown in Table. 2.

Table. 2: Setting Time Characteristics with different Jute loadings

\begin{tabular}{|l|l|l|l|}
\hline Description & $\begin{array}{l}\text { Jute } \\
\text { loading } \\
(\%)\end{array}$ & $\begin{array}{l}\text { Initial } \\
\text { Setting } \\
\text { time } \\
(\mathbf{m i n})\end{array}$ & $\begin{array}{l}\text { Final } \\
\text { Setting } \\
\text { Time } \\
(\mathbf{m i n})\end{array}$ \\
\hline Control & 0 & 38 & 316 \\
\hline RJC & 0.5 & 46 & 342 \\
\hline RJC & 1 & 52 & 359 \\
\hline RJC & 2 & 59 & 367 \\
\hline
\end{tabular}

\subsection{Compressive Strength of Cement Mortar}

The cement mortar incorporated with raw jute fibers and treated jute fibers are casted in to $70.6 \mathrm{~mm} \times 70.6 \mathrm{~mm} \times 70.6$ $\mathrm{mm}$ size cube specimens. The results of compressive strength of those specimens are shown below in Table. 3 .

Table. 3: Compressive Strength of cement mortar with different contents of Jute Fibers (raw)

\begin{tabular}{|l|l|l|l|}
\hline \multirow{2}{*}{ Description } & \multirow{2}{*}{$\begin{array}{l}\text { Jute } \\
\text { Content } \\
\text { (in \%) }\end{array}$} & $\begin{array}{l}\text { Compressive Strength } \\
\text { (in MPa) after }\end{array}$ \\
\cline { 3 - 4 } & $\begin{array}{l}\text { 7 days } \\
\text { curing }\end{array}$ & $\begin{array}{l}\text { 28 days } \\
\text { curing }\end{array}$ \\
\hline Control mix & - & 38.4 & 53.7 \\
\hline JFRM & 0.5 & 32.4 & 44.5 \\
\hline JFRM & 1 & 30.8 & 40.3 \\
\hline JFRM & 2 & 27.5 & 37.7 \\
\hline
\end{tabular}

Note:

Control- Nominal M20 (1:1.5:3) Concrete Mix;

JFRC-Jute Fiber Reinforced Concrete

\subsection{Mechanical Properties of Concrete Reinforced}

\section{with Jute Fibers}

a) Slump test for Workability of Concrete:

Slump test is conducted as per IS: 1199-1959 for testing the workability of Plain concrete and Jute Fiber Reinforced Concrete keeping W/C ratio as 0.5 as shown in Fig. 2.
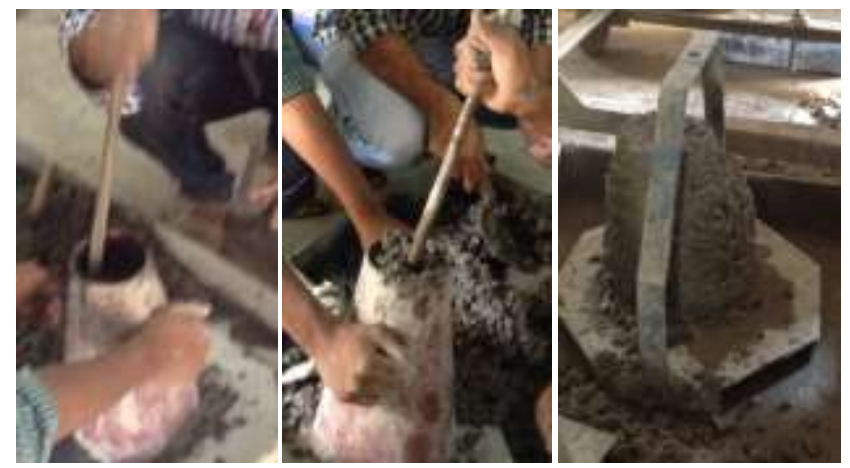

Fig. 2. Slump test

The slump tests for concrete with different contents of Jute fibers are conducted and are tabulated in Table. as shown below.

Table. 4: Slump Test of Concrete with different contents of Jute Fibers (untreated)

\begin{tabular}{|l|l|l|l|l|}
\hline S.No & Mix code & $\begin{array}{l}\text { Fiber } \\
\text { content } \\
\text { (in \%) }\end{array}$ & $\begin{array}{l}\text { W/C } \\
\text { ratio }\end{array}$ & $\begin{array}{l}\text { Slump } \\
\text { value } \\
\text { (in mm) }\end{array}$ \\
\hline 1 & Control & 0 & 0.5 & 62 \\
\hline 2 & RJFRC & 0.5 & 0.5 & 48 \\
\hline 3 & RJFRC & 1 & 0.5 & 45 \\
\hline 4 & RJFRC & 2 & 0.5 & 42 \\
\hline
\end{tabular}

Note:

Control- Nominal M20 (1:1.5:3) Concrete Mix; JFRC-Jute Fiber Reinforced Concrete

The variation of slump of concrete with different contents of jute fibers are shown in Fig. 3. 


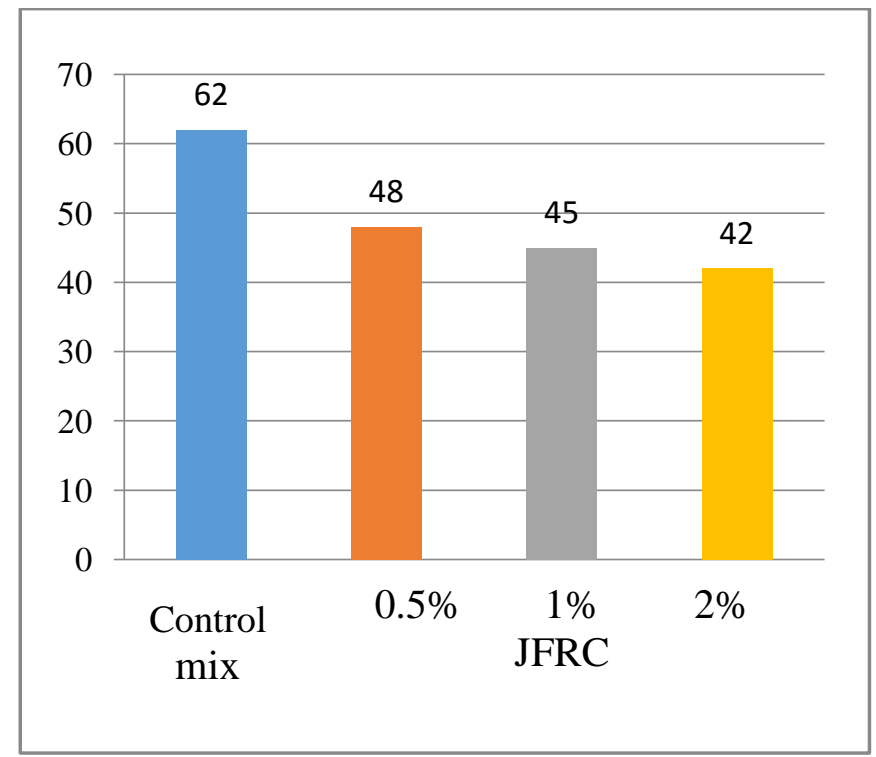

Fig. 3 Slump of Fresh Concrete with differentcontents of Jute fibers

Thus from the fig. it is seen that as the content of jute fibers increases the slump value i.e. workability of concrete decreases.

b) Compressive Strength:

Compressive strength of concrete is conducted as perIS: 516 - 1959 for testing the concrete cube specimens with different contents of Jute fibers for different curing periods such as $7,28,56,90$ days. The results of compressive strength test for different curing periods are as shown in Table.

TABLE. 5: Compressive Strength of Concrete Cube specimens for different curing periods

\begin{tabular}{|c|c|c|c|c|c|}
\hline \multirow{2}{*}{ Description } & \multirow{2}{*}{$\begin{array}{c}\text { Fiber } \\
\text { Content } \\
\text { (in \%) }\end{array}$} & \multicolumn{4}{|c|}{ Compressive Strength (in MPa) } \\
\cline { 3 - 6 } Control & 0 & 20.88 & 29.48 & 30.37 & 31.63 \\
\hline JFRC & 0.5 & 17.06 & 28.44 & 31.26 & 30.3 \\
\hline JFRC & 1 & 14.31 & 26.66 & 33.19 & 31.11 \\
\hline JFRC & 2 & 13.6 & 24.88 & 28.07 & 26.96 \\
\hline
\end{tabular}

Note:

Control- Nominal M20 (1:1.5:3) Concrete Mix;

JFRC-Jute Fiber Reinforced Concrete

The variation of compressive strength of concrete with different contents of jute fibers are shown in Fig. 4.

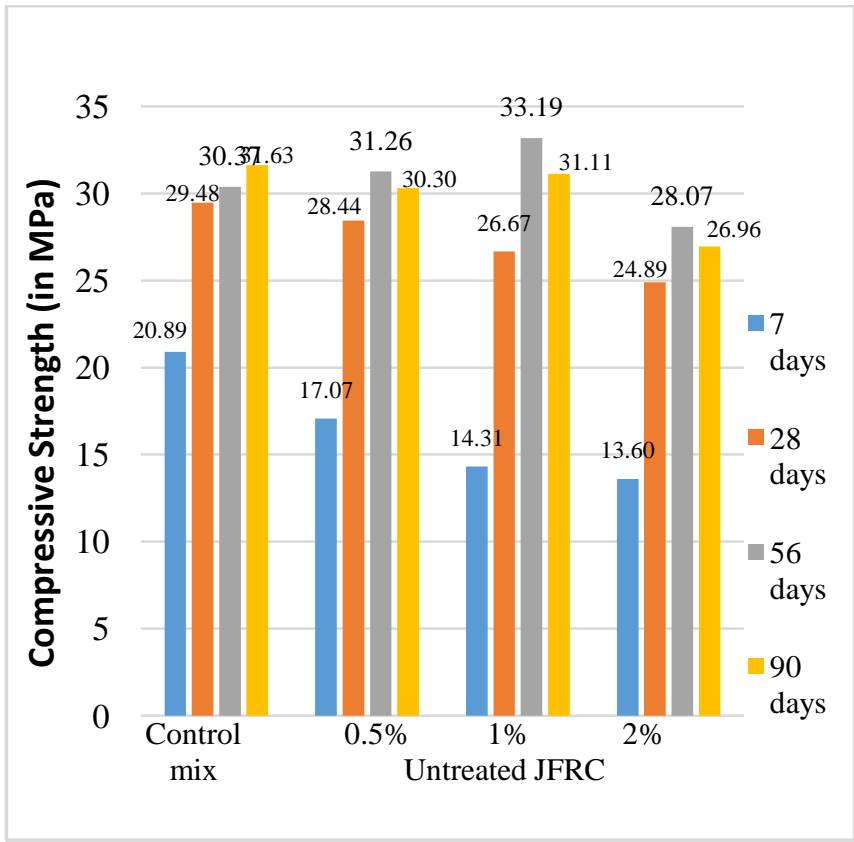

Fig. 4: Compressive strength of Concrete with differentcontents of Jute fibers

Thus from Fig., it is observed that at the initial stages i.e. 7 and 28 days the compressive strength of JFRC declines with increase in jute content with respect to ordinary concrete. But on further curing i.e. for 56 days, the compressive strength of JFRC increases upto $1 \%$ jute content and on further curing the compressive strength of JFRC decreases

c) Flexural Strength:

Flexural strength of concrete is conductedas perIS: 516 - 1959 for testing the concrete prism specimens with different contents of Jute fibers for different curing periods such as 7, 28, 56, 90 days. The results of flexural strength testfor different curing periods are as shown in Table. 6.

Table.6: Flexural Strength of Concrete Prism specimens for different curing periods

\begin{tabular}{|c|c|c|c|c|c|}
\hline \multirow{2}{*}{ Description } & \multirow{2}{*}{$\begin{array}{c}\text { Fiber } \\
\text { content } \\
\text { (in \%) }\end{array}$} & \multicolumn{4}{|c|}{ Flexural Strength (in MPa) } \\
\cline { 3 - 6 } & 7days & 28days & 56days & 90days \\
\hline Control & 0 & 3.2 & 4.4 & 5.1 & 5.3 \\
\hline RJFRC & 0.5 & 3.4 & 4.6 & 5.3 & 4.8 \\
\hline RJFRC & 1 & 3.6 & 4.8 & 5.8 & 5.4 \\
\hline RJFRC & 2 & 3.2 & 4 & 5.2 & 4.96 \\
\hline
\end{tabular}

Note:

Control- Nominal M20 (1:1.5:3) Concrete Mix;

JFRC-Jute Fiber Reinforced Concrete

The variation of flexural strength of concrete with different contents of jute fibers are shown in Fig. 5. 


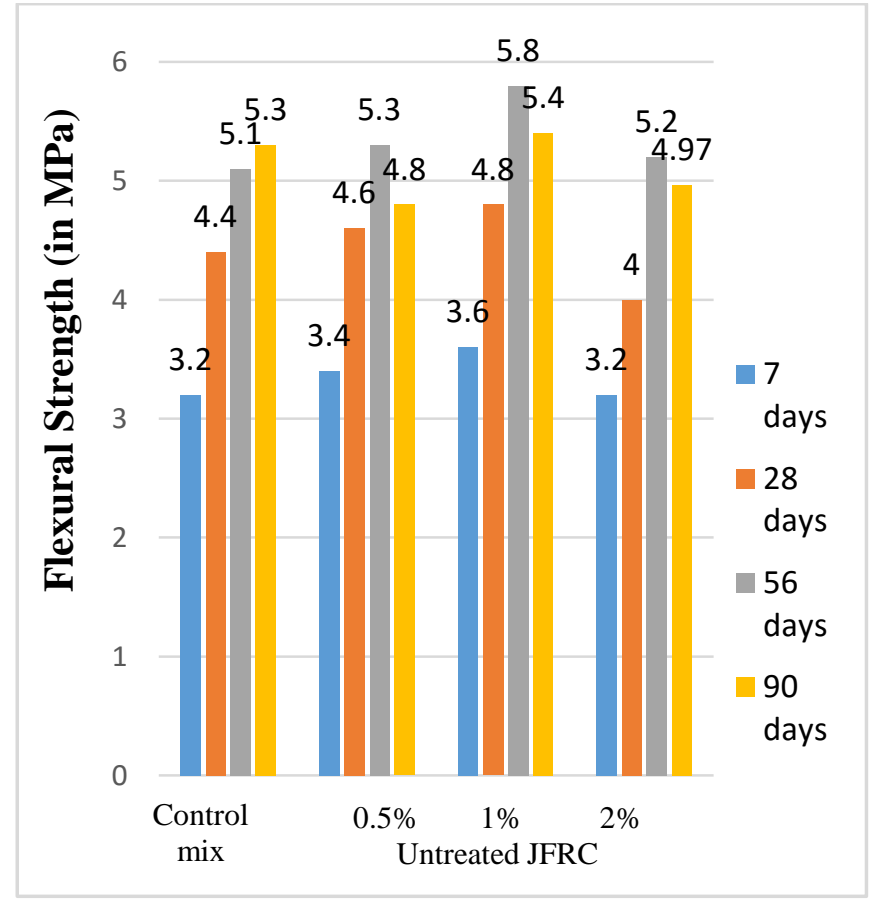

Fig. 5: Flexural strength of Concrete with differentcontents of Jute fibers

The flexural strength of concrete reinforced with jute fibers increases with jute content upto $1 \%$ and increase in strength continues up to 56 days of curing. On further curing, the flexural strength of JFRC declines w.r.t concrete.

\section{d) Split Tensile Strength:}

Split tensile strength of concrete is conductedas perIS: 5816 - 1999 for testing the concrete cylinder specimens with different contents of Jute fibers for different curing periods such as 7, 28, 56, 90 days. The results of flexural strength test for different curing periods are as shown in Table. 7.

Table. 7: Split Tensile Strength of Concrete cylinder specimens for different curing periods

\begin{tabular}{|c|c|c|c|c|c|}
\hline \multirow{2}{*}{ Description } & \multirow{2}{*}{$\begin{array}{c}\text { Fiber } \\
\text { Content } \\
\text { (in \%) }\end{array}$} & \multicolumn{4}{|c|}{ Split Tensile Strength (in MPa) } \\
\cline { 3 - 6 } & 7days & 28days & 56days & 90days \\
\hline Control & 0 & 1.98 & 3.34 & 3.42 & 3.53 \\
\hline RJFRC & 0.5 & 2.26 & 3.42 & 3.57 & 3.28 \\
\hline RJFRC & 1 & 2.39 & 3.55 & 3.75 & 3.67 \\
\hline RJFRC & 2 & 2.08 & 3.25 & 3.40 & 3.13 \\
\hline
\end{tabular}

Note:

Control- Nominal M20 (1:1.5:3) Concrete Mix;

JFRC-Jute Fiber Reinforced Concrete

The variation of split tensile strength of concrete with different contents of jute fibers are shown in Fig. 6.

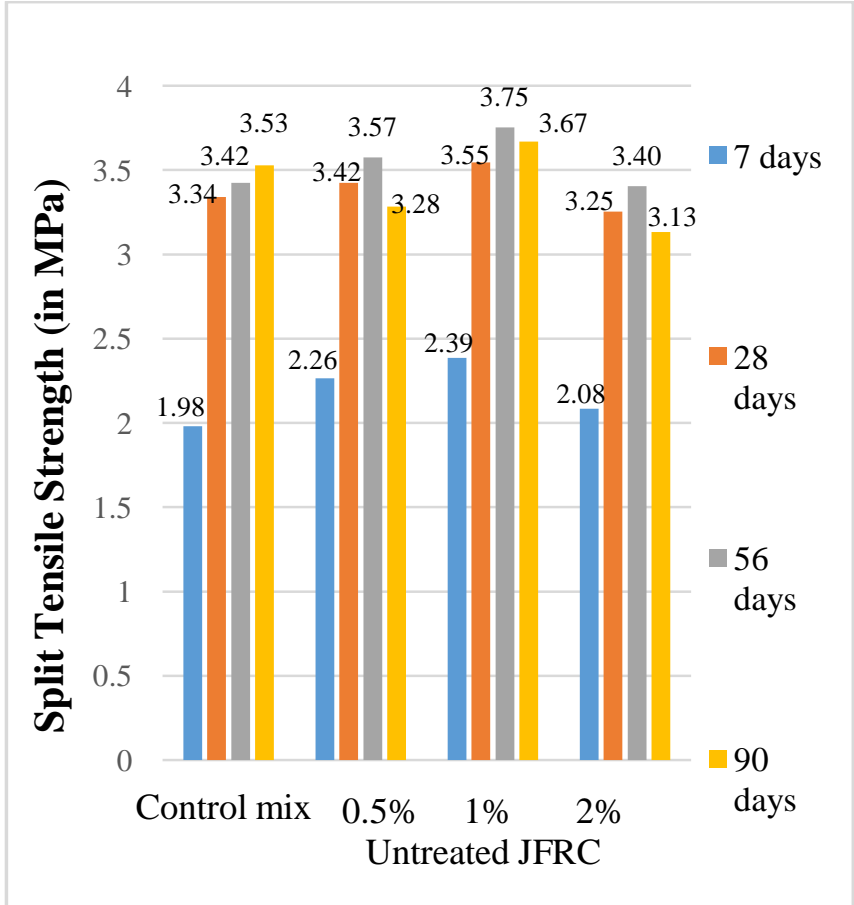

Fig. 6. Flexural strength of Concrete with differentcontents of Jute fibers

The split tensile strength of concrete reinforced with jute fibers increases with jute content upto $1 \%$ and increase in strength continues up to 56 days of curing. On further curing, the split tensile strength of JFRC declines w.r.t plain concrete.

\section{CONCLUSION}

This paper describes the influence of volume fraction of jute fibers on mechanical properties such as compressive strength, flexural strength and split tensile strength of concrete of mix proportion $1: 1.5: 3$ with w/c ratio as 0.5 . Based on the experimental analysis, the following conclusions are made:

(1) Compressive strength of cement mortar decreases with increase in jute loading.

(2) For a constant w/c ratio i.e. 0.5 , increase in the content of jute fibers, the workability of concrete decreases. Admixtures are required to enhance the workability properties of JFRC.

(3) Early age of compressive strength of concrete i.e. at 7 and 28 days, decreases with increase in jute content.

(4) For extension in period of curing i.e. 56 and 90 days the compressive the compressive strength increases up to $1 \%$ and then decreases with further increase jute loading.

(5) Flexural strength and split tensile strength of concrete increases up to $1 \%$ of jute loading and decreases with further increment.

(6) The mechanical strength properties of concrete with $1 \%$ jute content has attained their maximum strengths for a curing period of 56 days and on further curing i.e. for 90 days the mechanical strengths decreases.

(7) The maximum value of mechanical strength properties of JFRC i.e. $1 \%$ JFRC with curing period of 56 days are compared with 90 days of ordinary concrete are as follows. 


\begin{tabular}{|l|l|}
\hline Mechanical property & Increase in strength \\
\hline Compressive strength & $4.93 \%$ \\
\hline Flexural strength & $9.43 \%$ \\
\hline Split tensile strength & $6.23 \%$ \\
\hline
\end{tabular}

\section{REFERENCES}

[1]. ASTM D570-98, Standard Test Method for Water Absorption of Plastics, ASTM International, West Conshohocken, PA, 1998, www.astm.org.

[2]. IS: 4031 (Part 4)-1988. Methods of physical tests for hydraulic cement. Part 4. Determination of consistency of standard cement paste. Bureau of Indian Standards. New Delhi, India, Reaffirmed; 2005.

[3]. IS: 4031 (Part 5)-1988. Methods of physical tests for hydraulic cement. Part 5. Determination of initial and final setting Times. Bureau of Indian Standards. New Delhi, India, Reaffirmed; 2005.

[4]. IS: 4031 (Part 6) -1988. Methods of physical tests for hydraulic cement, Part 6, Determination of compressive strength of hydraulic cement other than masonry cement, Bureau of Indian Standards (2003), New Delhi, India, Reaffirmed; 2000.

[5]. IS, IS-516-1959. Methods of tests for strength of concrete. Bureau of Indian Standards New Delhi, India, Reaffirmed; 2004.

[6]. IS: 5816 - 1999. Method of test for splitting tensile strength of concrete, Bureau of Indian Standards (1999), New Delhi, India, Reaffirmed; 1999. 